\title{
PERAN ORANG TUA \\ DALAM MEMBANTU PERKEMBANGAN DIRI ANAK AUTISME
}

\author{
Nisa Hermawati \\ Fakultas Psikologi UIN Sunan Gunung Djati Bandung
}

No one in this world wants to have an abnormal child. All parents want their children normal. In fact, some of them have are not, for example autistic child. Autism is a rare developmental disorder involving inability to communicate with respond to other people. Therefore, it is parents' role to help autistic child in order to develop social and language skill. In helping autistic child parents must cooperate with experts by giving them information of their child.

Keywords: Parents, Child with autistic development

\section{Pendahuluan}

Secara psikologis dan sosial, konsep sehat bagi anak meliputi kondisi anak yang sangat baik yang memungkinkan mereka tumbuh dan berkembang dengan secara wajar, sesuai dengan tahutan sosial dan budaya lingkungan sekitar mereka. Anak dikatakan memiliki tanggung jawab terhadap perkembangan dirinya sendiri, lingkungan keluarga dan teman-teman sebayanya. Hal tersebut bisa dilihat dari cara mereka bergaul dengan temantemannya. Keberadaan jiwa anak dalam perkembangannya banyak berhubungan erat dengan lingkungan dan pendidikan yang mereka peroleh (Burhanuddin, 1999:83).

Setiap orang tua tentunya memiliki keinginan untuk memiliki anak yang sehat jasmani, rohani, anak yang pintar sehingga dapat berguna bagi dirinya, keluarga, masyarakat, dan negara. Tetapi pada kenyataannya harapan-harapan tersebut terkadang tidak sesuai dengan yang dinginkan, bukan karena hanya takdir semata, melainkan hukum alam dan didukung secara ilmiah, banyak faktor yang menjadikan harapan indah orang tua menjadi kabur entah kemana? Mungkin itulah yang disebut dengan rahasia dan rencana Tuhan yang tidak semuanya dapat diketahui oleh manusia sang makhluk yang penuh dengan segala keterbatasan.

Hal yang perlu disadari disini orang tua merupakan sumber yang sangat penting bagi anak-anaknya, sejak anak dilahirkan merekalah yang menjadi pembentuk awal sikap dan perilaku sang buah hati (Howart:1989:14). Sebagaimana hadits yang disabdakan Rasulullah SAW, "seorang anak itu bagaimana orang tuanya, mau jadi Yahudi atau Madjusi dan seterusnya?

Begitu juga teori Tabularasa John Lock mengatakan, "bahwa seorang anak terlahir 
seperti kertas kosong dan putih yang belum tergores oleh tinta sedikitpun", kertas tersebut akan menjadi merah ketika ditulisi tinta warna merah, begitu pun dengan warna-warna lainnya, dan sangat bergantung pada pelaku yang akan memberikan warna pada kertas tersebut.

Tidak dapat dipungkiri lagi, bahwa keluarga merupakan lingkungan primer bagi setiap individu, sejak ia lahir sampai datang masanya, ia meninggalkan rumah untuk membentuk keluarga sendiri, oleh sebab itu sebelum anak mengenal lingkungan masyarakat luar, pertama kali anak akan mengenal lingkungan keluarganya untuk dijadikan bagian dari kepribadiannya.

Autis berasal dari kata autos" yang berarti diri sendiri, adapun autistik adalah suatu gangguan perkembangan yang kompleks menyangkut komunikasi, interaksi sosial dan aktivitas imajinasi.

Upaya peningkatan dan pengembangan serta penyempurnaan penyembuhan anak autisme jelas bukan hanya dari pihak para ahli (terapis) saja, karena ketika anak autisme melakukan terapis hanya memiliki waktu dua jam untuk mendapat pengarah dan pembelajaran, sedangkan lingkungan rumah tempat perlindungan anak serta peran orang tua jelas menjadi salahsatu upaya agar anak dapat mengembangkan diri secara optimal.

Orang tua memiliki peran dominan dalam upaya penyembuhan, karena orang yang paling mengerti dan paling dimengerti oleh anak khususnya penyandang autis. Untuk itu orang tua tetap dituntut untuk melakukan sesuatu yang bemanfaat bagi kesembuhan anaknya.

Dengan perkembangan anak, peran sebagai orang tua pun mengalami perubahan. Mula-mula, tanggungjawab orang tua jelas sebagai pemberi, pelindung dan pendidik, yaitu menjaga agar segala kebutuhannya terpenuhi dan menghindarkannya dari berbagai krisis. Ketika usia anak bertambah, mereka memerlukan orang tua dengan cara yang lain, yaitu membimbing, mengajar, menghibur dan menerangi, menjalin keakraban dan tempat berbagi rahasia.

Peran sebagai orang tua menuntut untuk terus menerus dan secara luwes menyesuaikan reaksi terhadap perkembangan kemampuan anak. Namun kadang-kadang orang tua terus bertahan pada suatu peran walaupun saatnya sudah tiba untuk berubah, meremehkan kemampuan anak serta keinginannya untuk bertanggungjawab sehingga orang tua terus bertindak secara berlebihan yang tidak perlu dan bahkan tidak diinginkan.

Orang tua mengenal atau mengira telah mengenal anaknya sedemikian baiknya sehingga orang tua berhenti menilai kembali informasi tentang mereka, lupa bahwa mereka sesungguhnya terus berkembang dan berubah.

Pada saat ini banyak sekali orang tua yang menitipkan anak-anaknya di tempat penitipan anak. Sebagai salah satu contoh, saat inipun banyak orang tua yang anaknya penyandang autisme menitipkan anaknya di yayasanyayasan, mereka tidak semuanya selalu mengantarkan anaknya untuk bersekolah, 
terkadang anak hanya datang bersama seorang supir atau pengasuhnya.

Pola perilaku orang tua menentukkan perkembangan jiwa anak. Anak yang tumbuh dari keluarga sehat akan tumbuh percaya diri. Orang percaya diri ialah yang merasa puas dengan dirinya. Percaya diri terbagi ke dalam dua yakni lahir dan batin. Percaya diri secara batin ialah memberikan perasaan dan anggapan bahwa diri dalam keadaan baik; sedangkan percaya diri secara lahir memungkinkan diri tampil dan berperilaku dengan cara menunjukkan kepada dunia luar bahwa diri yakin akan diri sendiri. Percaya diri lahir dan batin saling mendukung, keduanya akan membentuk karakter kepribadian yang efektif.

Persoalan anak autisme, orang tua dituntut mengerti hal-hal seputar autisme dan mampu mengorganisir kegiatan terapi untuk anaknya. Para ahli tidak akan dapat bekerja tanpa peran serta orang tua, dan terapi tidak akan efektif bila orang tua tidak dapat bekerja sama, karena umumnya para ahli tersebut bekerja berdasarkan data yang diperoleh dari orang tua yang paling memahami dan berada paling dekat dan hidup bersama dengan anaknya.

\section{Peran Orang tua}

Orang tua adalah pembina pribadi yang pertama dalam hidup anak. Kepribadian orang tua, sikap dan cara hidup mereka, merupakan unsur-unsur pendidikan secara tidak langsung dengan sendirinya akan masuk ke dalam pribadi anak yang sedang berkembang. Perlakuan orang tua terhadap semua anak merupakan unsur pembinaan dalam pribadi anak. Perlakuan keras, akan berlainan akibatnya dari perlakuan yang lembut dalam pribadi anak (Darajat, 1991 : 56). Menjadi orang tua memang tidak mudah. Menjadi orang tua sama halnya dengan menanggung banyak beban tanggung jawab, yakni tanggung jawab untuk mengasihi, mengasuh serta membesarkan anak dengan baik. Tak ada formula khusus untuk itu, juga tidak ada ramuan yang pasti menjamin saat menjalani tugas mulai itu. Jack Canfield, penulis buku Chiken Soup for the Mother's Soul, mengatakan meski ingin melakukan semua hal, kebanyakan orang tua sering tidak tahu bagaimana melakukannya.

Mereka tidak mengerti, tidak memiliki atau jarang mendapatkan kursus untuk menjadi orang tua yang baik. Menurut John Gray, bagian yang penting dalam tugas mengasuh anak adalah mencurahkan kasih sayang. Namun kasih sayang saja tidaklah cukup, menurut Reni Akbar Hawadi menambahkan, makhluk kecil ciptaan Tuhan itu harus dipenuhi kebutuhan dasarnya, yakni kebutuhan fisik, emosi, intelektual, sosial ataupun moralnya (Krisnawati, $2005: 5$ ).

Orang tua wajib memikul tanggung jawab untuk memberikan pendidikan yang benar kepada anak di rumah dan di lingkungan luar dan memelihara mereka dengan cinta kasih sayang. Dengan demikian perilaku sosial dan pergaulan mereka dengan orang lain bersifat luhur, lembut dan konsisten.

Cinta kasih sayang dalam keluarga selain berfungsi menjaga keharmonisan rumah 
tangga, juga merupakan media yang baik untuk tumbuh kembang anak, dan dapat meningkatkan daya kreativitas dalam berkarya dan produktivitas serta menciptakan lingkungan yang damai dalam masyarakat, sehingga tercipta keluarga yang sejahtera dan mandiri. Orang tua lebih mengutamakan pembinaan anak-anak sebijaksana mungkin dengan penuh cinta kasih.

Orang tua juga wajib memberikan motivasi kepada anak-anak, yakni dengan memberikan hadiah atau penghargaan. Orang tua memiliki peranan mendasar dalam mendidik anak hingga pada persoalan sekecilkecilnya. Mereka harus mengajarkan kepada anak cara berbicara, duduk, cara memandang dan berhubungan dengan orang lain di rumah, sekolah dan masyarakat. Anak-anak sebagai tanaman mulia yang sedang tumbuh sehingga akan meniru garis kedua orang tuanya dalam hal-hal yang besar maupun kecil. Orang tua bagaikan bayangan bagi mereka.

\section{Autisme}

Autis berasal dari kata autos" yang berarti diri sendiri, adapun autistik adalah suatu gangguan perkembangan yang kompleks menyangkut komunikasi, interaksi sosial dan aktivitas imajinasi. Gejalanya mulai sebelum anak berusia 3 tahun. Bahkan pada autistik infanti gejalanya sudah ada sejak lahir, diperkirakan $75 \%$ - $80 \%$ penyandang autis ini mempunyai retardasi mental, sedangkan $20 \%$ dari mereka mempunyai kemampuan yang cukup tinggi untuk bidang-bidang tertentu (savant) (Puterakembara, 2008).
Anak penyandang autis mempunyai masalah/gangguan dalam bidang: 1) Komunikasi; 2) Interaksi sosial; 3) Gangguan sensoris; 4) Pola bermain; 5) Perilaku; 6) Emosi.

Penyebab autisme dahulu diperkirakan karena pola pengasuhan yang kaku dan obsesif dalam suasana emosional yang dingin, ibu kurang memperhatikan anak, atau tidak menghendaki kehadiran anak sehingga anak menarik diri. ini dikemukakan oleh Bruno Bettleheim, menurutnya anak-anak ini menolak hidup dalam masyarakatnya karena merasa tidak diterima oleh keluarganya, terutama oleh ibunya karena tidak bisa menunjukkan kehangatan pada anaknya. Tetapi teori ini akhirnya terbantah karena ternyata ada anak autis yang terlahir di keluarga yang memiliki perhatian besar terhadap anaknya.

Beberapa teori terakhir mengatakan bahwa faktor genetika memegang peranan penting pada terjadinya autistik. Bayi kembar satu telur akan mengalami gangguan autis yang mirip dengan saudara kembarnya. Juga ditemukan beberapa anak dalam satu keluarga besar mengalami gangguan yang sama. Selain itu gangguan virus seperti rubella, toxo, herpes, jamur, nutrisi yang buruk, perdarahan, keracunan makanan, pada kehamilan dapat menghambat pertumbuhan sel otak yang dapat menyebabkan fungsi otak bayi yang dikandung terganggu terutama fungsi pemahaman, komunikasi dan interaksi.

Akhir-akhir ini dari penelitian terungkap juga hubungan antara gangguan pencernaan dan gejala autistik. Ternyata lebih dari $60 \%$ 
penyandang autistik ini mempunyai sistem pencernaan yang kurang sempurna .

Setiap anak autisme mempunyai karakteristik yang berbeda-beda, maka setiap anak memiliki gaya tersendiri dalam upaya mencerna informasi secara efektif, pada umumnya anak belajar melalui indera penglihatan, perabaan dan pendengaran. Anak juga mempunyai aneka gaya dalam mengingat. Dalam gaya belajar dan ciri khas autisme ada beberapa gaya belajar yang dominan pada diri mereka (Dyah Puspita, 2003).

Berikut kiat praktis mempersiapkan dan membantu anak autis mengikuti pendidikan di sekolah umum :

1) Rote learner: anak yang memakai gaya belajar ini, cenderung menghapal informasi apa adanya, tanpa memahami arti simbol yang mereka hapalkan. Contoh : anak dapat mengucapkan huruf dengan baik secara urut, tetapi sesungguhnya tidak tahu bahwa huruf itu apabila digabung dengan huruf lain akan menjadi kata yang mengandung makna; 2) Gestalt Learner: Bila anak menghafalkan kalimat-kalimat secara utuh tanpa mengerti arti kata per kata yang terdapat pada kalimat tersebut, anak cenderung belajar menggunakan gaya "gestalt" (melihat sesuatu secara global). Berbeda dengan anak yang tidak autis yang belajar justru mulai dengan kata per kata, anak autis dengan gaya gestalt akan belajar bicara dengan mengulang seluruh kalimat. Ia ingat seluruh kejadian, tetapi sulit memilah mana yang penting dan mana yang tidak, ia mungkin akan sulit menjawab pertanyaan tentang salah satu yang detail. Misalnya : Anda berikan mainan karet yang biasanya dimainkan sambil mandi dan mengatakan "letakkan di air" ia akan dapat melakukannya, tetapi bila Anda berikan mainan yang sama dan mengatakan "letakkan di rak mainan " ia akan tetap meletakkan di air. Ia tidak paham makna kata letakan, tetapi ia hanya mengasosiasikan, seluruh kalimat dengan kebiasaannya saja; 3) Visual Learner: Anak dengan gaya "visual" senang melihat-lihat buku atau gambar atau nonton TV dan umumnya lebih mudah mencerna informasi yang dapat mereka lihat, daripada yang hanya dapat mereka dengar. Berhubung penglihatan adalah indera terkuat mereka, tidak heran banyak anak autis sangat menyukai TV/gambar;

4) Hands and Learner: Anak yang belajar dengan gaya ini, senang mencoba-coba dan biasanya mendapatkan pengetahuan melalui pengalamannya. Mulanya ia mungkin tidak tahu apa arti kata "buka" tetapi sesudah Anda letakkan tangannya di pegangan pintu dan membantu tangannya membuka sambil Anda katakan "buka", ia segera tahu bahwa bila Anda katakan "buka", berarti....ia pergi ke pintu dan membuka pintu itu. Anak-anak ini umumnya senang menekan tombol-tombol, membongkar mainan dan sebagainya; 5) Auditory Learner: Anak dengan gaya belajar ini senang bicara dan mendengarkan orang lain bicara. Ia mendapatkan informasi melalui pendengarannya. Jarang sekali anak autis bergantung sepenuhnya pada gaya ini dan biasanya menggabungkannya dengan gaya lain. 
Tiap penyandang autisme sangat berbeda dalam mengolah dan memberikan respon pada informasi yang ia dapat sehingga materi untuk terapi dan proses belajar mengajar haruslah dibuat secara khusus dengan mengacu pada kelebihan dan kekurangan masing-masing anak. Kemampuan anak autisme dapat berubah-ubah dari hari kehari dikarenakan sulitnya berkonsentrasi atau mengolah informasi dan timbulnya rasa takut. Pada hari pertama anak akan dapat terlihat baik dalam mempelajari sesuatu tetapi pada hari berikutnya mendapat kesulitan belajar. Perubahan yang terjadi disekitarnya serta rasa takutnya dapat langsung mempengaruhi kegiatan belajarnya (Puterakembara, 2008).

\section{Peran Orang tua dalam Membantu}

\section{Perkembangan Diri Anak Autisme}

Orang tua memainkan peranan yang sangat penting dalam membantu perkembangan anak. Seperti anak-anak lainnya, anak autis terutama belajar melalui permainan.

Berikut beberapa hal yang harus dilakukan orang tua penyandang autis kepada anaknya: 1) Bergabunglah dengan anak ketika dia sedang bermain; 2) Tariklah anak dari perilaku dan ritualnya yang sering diulang-ulang; 3) Tuntunlah mereka menuju kegiatan yang lebih beragam; 4) Masuklah ke dunianya untuk membantu mereka masuk ke dunia luar; 5) Berikanlah pujian ketika anak selesai menyelesaikan tugasnya dengan baik; 6) Temukan cara lain untuk mendorong perilaku yang baik dan untuk mengangkat harga dirinya (Uci, 2008).
Berikut beberapa hal yang harus dilakukan oleh para orang tua yang memiliki peran dalam perkembangan anak autisme, yakni:

1) Sebelum Diagnosa: Orang tua yang memperhatikan perkembangan anaknya dan cukup memiliki informasi mengenai kriteria anak, umumnya sudah dapat merasakan dalam hati kecilnya bila anaknya mengalami penyimpangan dalam perkembangan sejak masa bayi. Meski demikian, mereka tidak sepenuhnya paham apa yang terjadi, sehingga memerlukan diri untuk datang pada dokter/psikiater atau psikolog. Tujuan mereka datang adalah untuk: a) Memperoleh pendapat profesional mengenai keadaan anak; b) Mendapatkan pengarahan untuk langkah penanganan selanjutnya.

Tidak mudah menjalani fase ini, karena orang tua manapun ingin anaknya "baik-baik saja". Beberapa orang tua bahkan menunda pergi ke dokter/psikiater/psikolog karena khawatir akan menerima berita buruk. Selain itu ada juga orang tua yang justru malah menyepelekan keadaan anaknya, misalnya dengan berkata "ah, anak laki-laki biasa seperti ini, nanti juga bisa bicara"; 2) Saat Diagnosa: Siapapun yang mendapatkan vonis keadaan tidak menyenangkan, pasti bereaksi. Pada umumnya, reaksi pertama orang tua yang anaknya dikatakan menyandang autisme adalah tidak percaya (shock). Hal yang harus dilakukan oleh orang tua yakni merangkul dan berempati sehingga memahami anak sepenuhnya; 3) Sesudah Diagnosa: Orang tua diharapkan akan selalu berusaha sekuat tenaga agar anaknya dapat berkembang lebih baik, 
maka orang tua harus selalu mencari cara agar dapat membantu perkembangan diri anak autisme seperti: Memahami keadaan anak apa adanya: a) Memahami kebiasaan-kebiasaan anak; b) Menyadari apa yang bisa dan belum bisa dilakukan anak; c) Memahami penyebab perilaku buruk atau baik anak; d) Membentuk ikatan batin yang kuat yang akan diperlukan dalam kehidupan di masa depan; Mengupayakan alternatif penanganan sesuai kebutuhan anak: a) Bagaimana anak memproses informasi, bereaksi terhadap sensasi, merencanakan tindakan dan menuruti perilaku atau pikiran mereka; b) pola interaksi dan komunikasi anak; c) kepribadian anak; d) pola pengasuhan;

Memperhatikan penanganan anak di rumah:

a) Menemani dan memastikan adanya interaksi aktif antara anak dengan orang tua yang ada di sekitarnya; b) Memberikan pengalaman sebanyak mungkin disertai pengarahan; c) Memberikan kesempatan pada anak untuk melakukan berbagai hal; d) Menemani anak dari mulai bangun tidur hingga tertidur kembali; e) Mengupayakan pengawasan yang cukup ketat bagi anak; f) Menghindari benda yang akan dimakan ataupun benda yang dapat menyakiti diri sendiri maupun orang lain; Melakukan evaluasi secara periodik atas apapun program penanganan pada anak; Bersikap positif dan percaya diri dalam menangani perkembangan anak.

\section{Daftar Pustaka}

Burhanudian, Yusak. (2000). Kesehatan Mental. Bandung: Pustaka Setia.

Darajat, Zakiah. (1991). Ilmu Jiwa Agama. Jakarta: Bulan Bintang.

Howard, Marion. (1989). Orang Tua Membimbing. Jakarta: Arcan.

Krisnawati, Christina. (2005). Menjadi Orang Tua dan Sahabat Terbaik Anak Anda. Yogyakarta: Curiosita.

Puspita, Dyah. (2002). Artikel Kiat Praktis Mempersiapkan dan Membantu Anak Autis Mengikuti Pendidikan di Sekolah Umum.

Puterakembara. (5 Maret 2008). Artikel Duniaku adalah Duniamu. www.google.com.

Uci. (2008). (Balita anda) artikel autis. Program Intervensi dini akan Membantu orang tua dan anak autis. www.mail-archieve.com/balita anda@ba. 
Psympathic, Vol. I, No.1, 2008: 107 - 114 